\title{
Intense Appearance Of Chestnut Gall Wasp (Dryocosmus Kuriphilus Yasumatsu) \\ In Bosnia And Herzegovina
}

\section{Z Delalić*}

University of Bihac, Biotechnical Faculty, Bosnia and Herzegovina

*Corresponding Author: Z Delalić, University of Bihac, Biotechnical Faculty, Bosnia and Herzegovina.

Received: July 04, 2019; Published: August 06, 2019

DOI: 10.31080/ASAG.2019.03.0597

\begin{abstract}
This paper presents the research of biological characteristics, prevalence, intensity of appearance in year 2016 and 2017 and a prognosis of further expansion of chestnut gall wasp (Dryocosmus kuriphilus Yasumatsu) in Bosnia and Herzegovina. Chestnut gall wasp is an invasive, quarantine pest which was first time registered in year 2015 on 34 locations in Bosnia and Herzegovina. In year 2016, this specific pest was found on 41 location, and in 2017 it was found on 48 locations. Research has shown that the expansion location of chestnut gall wasp has expanded in relation to localities from the first findings in 2015. Based on the research results, a hot spot map of chestnut gall wasp in Bosnia and Herzegovina has been made for 2017. First galls were found on June 2nd in 2016, and on June 5th in 2017. First adult chestnut gall wasp was found on July 3rd in 2016, and on July 8th in 2017.The study also determined the intensities of the D. kuriphilus phenomenon in all sites where this pest was found, and the intensity of occurrence (category 3 ) was the highest on the sites in the municipality of Velika Kladuša and Cazin. Intensive appearance of chestnut gall wasp creates a possibility of expansion of chestnut blight fungus (Cryphonectria parasitica (Murr.)Barr. According to research in Switzerland, there is a possibility for new entry spots for the spores of chestnut peel cancer through abandoned galls of chestnut gall wasps, which fungi can saprophytically populate, which can cause spreading of the infection to neighboring branches. Due to that problem, it is necessary to conduct a research to determine if there is a risk of spreading of this disease in the areas of sweet chestnut (Castanea sativa) in Bosnia and Herzegovina.
\end{abstract}

Keywords: Chestnut Gall Wasp (Dryocosmus kuriphilus); Sweet Chestnut (Castanea sativa); Intensity Appearance; Invasive Species

\section{Introduction}

Genus Castanea Mill. belongs to family Fagaceae, and it includes 7 economically and ecologically significant wood spieces which are widespread in a temperate forest belt of the northern hemisphere [25]. The European sweet chestnut (Castanea sativa Mill.) is found in the Mediterranean from the Caspian lake to the Atlantic Ocean, where chestnut forests occupy an area of 2.530 .000 ha $[4,8]$. There are three significant locations in Bosnia and Herzegovina where European chestnuts are represented.The first Herzegovinian site is 200 hectares, the second in eastern Bosnia is 300 hectares. The third richest chestnut area in Bosnia is the area of northwest Bosnia, covering 7000 hectares [14]. In recent few decades, sweet chestnut is a highly endangered species due to the chestnut blight fungus (Cryphonectria parasitica (Murr.) Barr. which causes drying and decaying of trees. In Bosnia and Herzegovina, this disease is a major cause of the devastation of chestnut forests [24]. Because of its exceptional aggressiveness and pathogenicity, C. parasitica has been included in the IUCN (International Union for Conservation of Nature) list, among hundred world's most dangerous invasive species that are the greatest threat to biodiversity [19]. In Europe it has been proclaimed a quarantine pathogen and is included in the EPPO A2 list (European and Mediterranean Plant Protection Organization). A new invasive, quarantine pest that is threatening to the chestnut stands is the chestnut gall wasp (Dryocosmus kuriphilus Yasumatsu). It originates from China, and for first time, it was discovered outside of its natural area in Japan in 1941[18] and on the Korean peninsula in 1961 [22]. Outside of Asia, this pest was first recorded in the US in 1974 [22] and Nepal in 1999 [3]. In Europe, it was first recorded in 2002, in Italy, in the region Piemont [23], 3 years later (2005) in Slovenia [13] and 2009 in Hungary [5]. Appearance of the pest has been confirmed in Netherlands (2010), Austria (2011), Czech Republic (2012), Slovakia (2012), Spain (2012) and Germany (2012) [20]. Chestnut gall wasp is a dangerous pest that causes a large loss of yield due to the appearance of the galls on leaves and on the new growth of the tree [2]. In Croatia it was first recorded in 2010 [15], and in Bosnia and Herzegovina in 2015 [6]. New researches have shown that chestnut blight fungus could appear more intensively after the attack of the chestnut gall wasp [21]. The aim of this research is to show biological characteristics in 2016 and 2017, to establish its localities of distribu- 
tion, the intensity of occurrence and to predict the spread of the chestnut gall wasp in Bosnia and Herzegovina.This paper will consider the possibility of enhancing of the chestnut blight fungus $(C$. parasitica) due to the occurrence of the chestnut gall wasp.

\section{Material and Methods of Work}

The distribution and intensity of the infection with chestnut gall wasp were made on a wide area of Una-Sana Canton (northwestern part of Bosnia and Herzegovina), where chestnut forms a stand or appears with other deciduous species. The biology of chestnut gall wasp was investigated at the sites of Pećigrad, Donja Koprivna (Municipality of Cazin) and at the locations of Johovica and Gornja Vidovska (Municipality of Velika Kladuša). Galls from chestnut plants were collected every week from May 15th till June 20th of 2016 and 2017. They were taken to entomological laboratory of the Faculty of Biotechnology for analysis. Galls were opened to track larval stages, the start and duration of the galls, and the emergence of the adults.The intensity of the appearance on chestnut trees was evaluated on the number of galls on the new branch growth (Table 1). At each location, 10 chestnut trees were investigated by visual inspection of the new growth (as far as the view could reach from the ground level). The intensity of the attack is rated by categories: 0-3.

\begin{tabular}{|c|c|c|}
\hline $\begin{array}{c}\text { Intensity of } \\
\text { infection } \\
\text { (numbered) }\end{array}$ & $\begin{array}{l}\text { Intensity of } \\
\text { infection } \\
\text { (descriptive) }\end{array}$ & Determination method \\
\hline 0 & No galls & $\begin{array}{l}\text { Visual inspection of new growth } \\
\text { on the tree (as fas as could be } \\
\text { seen from the ground level) has } \\
\text { shown no galls. }\end{array}$ \\
\hline 1 & Weak attack & $\begin{array}{l}\text { One gall per new growth, but } \\
\text { only on some growth on the } \\
\text { tree, by visual inspection they } \\
\text { are not found easily, but they } \\
\text { have to be looked for. }\end{array}$ \\
\hline 2 & $\begin{array}{l}\text { Medium } \\
\text { attack }\end{array}$ & $\begin{array}{l}\text { 1-5 galls per growth, but not on } \\
\text { all which could be seen from the } \\
\text { ground level. }\end{array}$ \\
\hline 3 & Strong attack & $\begin{array}{l}\text { More than } 5 \text { galls per growth, } \\
\text { all growth that could be seen } \\
\text { from the ground level has been } \\
\text { attacked. }\end{array}$ \\
\hline
\end{tabular}

Table 1: Intesity of the attack of chestnut plants (Castanea sativa) with chestnut gall wasp (Dryocosmus kuriphilus) [16].

\section{Results and Discussion}

Chestnut gall wasp was found at 41 location in 2016 in Bosnia and Herzegovina, and in 2017 it has been found at 48 locations. The biggest number of locations is located in the areas of Cazin and Velika Kladusa, where chestnut is present in large areas (Table 2 and 3). Based on the appearance locations of chestnut gall wasp, a hot spot map has been made in 2017 (Figure 1). D. kuriphilus is one of 2 species from phylum Cynipini which causes galls on species from the Castanea genus [1]. Monitoring of the biology at 4 locations found that this wasp has one generation per year. During the spring, during vegetative growth on leaves and new branch growth of sweet chestnut, the insect formed 5-20 mm large, easily visible reddish or green galls.In galls, there are one or more chambers wuth white larvae. The older galls are brown and hard. Chestnut gall wasp is a monophagous species that is fed with chestnut only. In the beginning of June, white pupae are formed which turn darker in a few days. First galls were found on June $2^{\text {nd }}$ in 2016 and on June $5^{\text {th }}$ in 2017, which is a ecological factor. First adult chestnut gall wasp was found on July $3^{\text {rd }}$ in 2016 and on July $8^{\text {th }}$ in 2017. In 2015 in this area, first grown species was registered on July $10^{\text {th }}$ [6]. There is one generation per year, and it reproduces parthenogenetically (no males), and embryo is produced asexually without fertilization [18]. During the research, it was found that the area of spreading of chestnut gall wasp has spread to the locations of its first findings in 2015 [6]. In 2016 and 2017 there were 14 new locations compared to 2015. Intensity of the attack (category 3) was the largest in the municipalities of Velika Kladusa and Cazin. The chestnut forests of this municipality borders with chestnut forests of the neighboring state of Croatia, from where this chestnut gall wasp has entered. However, high attack intensities have been recorded on a large number of locations in 2017, as the chestnut gall wasp has spread, and is present for 3 years. Although the wasp has determined first time in 2015, most likely it was present in the perimeter areas before. This could be concluded on the presence of a large number of old, dry galls. As a consequence of the gall wasp attack, the drying of chestnut new growth as well as the complete drying of young plants has been observed. In each subsequent year, the number of females increases, which contributes to the parthenogenetical reproduction and greater increase of the galls.The third year of occurrence can be classified in the greatest intensity of occurrence 3 . These are mostly locations where the wasp appeared in 2015. The occurrence of the wasp where it first appeared is classified in category 1.

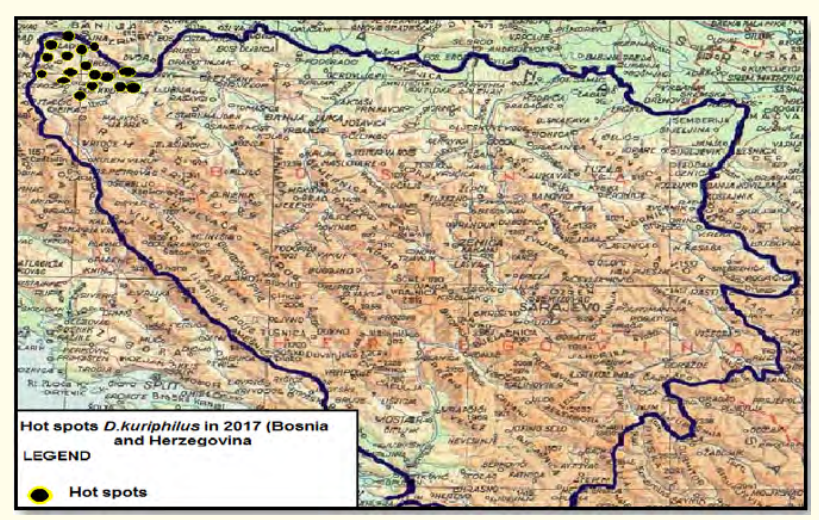

Figure 1: Hot spots map of Dryocosmus kuriphilus in 2017 (Bosnia and Herzegovina). 


\begin{tabular}{|c|c|c|c|c|c|c|c|}
\hline \multicolumn{4}{|c|}{ Locality (Municipality of Velika Kladuša) } & \multicolumn{4}{|c|}{ Locality (Municipality of Cazin) } \\
\hline \multicolumn{4}{|c|}{ Infestation rate } & \multicolumn{4}{|c|}{ Infestation rate } \\
\hline \multicolumn{2}{|c|}{2016.} & \multicolumn{2}{|l|}{2017.} & 2016. & \multicolumn{3}{|c|}{2017.} \\
\hline Mala Kladuša & 3 & Mala Kladuša & 3 & Skokovi & 3 & Skokovi & 3 \\
\hline Todorovo & 2 & Todorovo & 3 & Rošići & 3 & Rošići & 3 \\
\hline Šumatac & 2 & Šumatac & 3 & Ponjevići & 2 & Ponjevići & 3 \\
\hline \multirow[t]{2}{*}{ Gornja Vidovska } & \multirow[t]{2}{*}{3} & \multirow[t]{2}{*}{ Gornja Vidovska } & \multirow[t]{2}{*}{3} & Krakača & 3 & Krakača & 3 \\
\hline & & & & Gnjilavac & 3 & Gnjilavac & 3 \\
\hline Drenovac & 2 & Drenovac & 3 & Pećigrad & 3 & Pećigrad & 3 \\
\hline Marjanovac & 3 & Marjanovac & 3 & Šabići & 3 & Šabići & 3 \\
\hline Johovica & 2 & Johovica & 3 & Mujakići & 3 & Mujakići & 3 \\
\hline Fazlići & 2 & Fazlići & 3 & Krivaja & 3 & Krivaja & 3 \\
\hline Zborište & 3 & Zborište & 3 & Ljubijankići & 2 & Ljubijankići & 3 \\
\hline Kumarica & 3 & Kumarica & 3 & Brezova Kosa & 3 & Brezova Kosa & 3 \\
\hline Stabandža & 2 & Stabandža & 3 & Bašče & 2 & Bašče & 2 \\
\hline Brdo & 2 & Brdo & 2 & D.Koprivna & 2 & D.Koprivna & 3 \\
\hline Crvarevac & 1 & Crvarevac & 3 & G.Koprivna & 2 & G.Koprivna & 2 \\
\hline Jablan & 1 & Jablan & 2 & Karnova Glavica & 2 & Karnova Glavica & 3 \\
\hline Podzvizd & \multirow[t]{5}{*}{1} & Podzvizd & 2 & Lanište & 1 & Lanište & 2 \\
\hline \multirow[t]{4}{*}{ 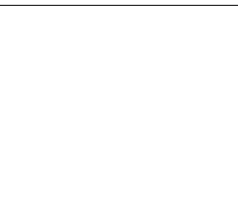 } & & Šiljkovača & 1 & Pivnice & 1 & Pivnice & 2 \\
\hline & & & & & & Bajramovići & 1 \\
\hline & & & & & & Stijena & 1 \\
\hline & & & & & & Šljemena & 1 \\
\hline
\end{tabular}

Table 2: Localities and infestation rates of D.kuriphilus (2016. i 2017.) on municipalities Velika Kladuša and Cazin.

\begin{tabular}{|l|c|c|c|c|c|c|c|}
\hline \multicolumn{3}{|c|}{ Locality (Municipality of Bužim) } & \multicolumn{3}{c|}{ Locality (Municipality of Bosanska Krupa) } \\
\hline \multicolumn{3}{|c|}{ Intenzitet napada } & \multicolumn{3}{c|}{ Intenzitet napada } \\
\hline \multicolumn{2}{|c|}{ 2016. } & \multicolumn{2}{c|}{$\mathbf{2 0 1 7}$} & \multicolumn{2}{c|}{ 2016. } & \multicolumn{2}{c|}{$\mathbf{2 0 1 7}$} \\
\hline Bag & 2 & Bag & 3 & Tromeđa & 2 & Tromeđa & 3 \\
\hline Vrhovska & 2 & Vrhovska & 3 & Bućevci & 1 & Bućevci & 2 \\
\hline Zaradostovo & 2 & Zaradostovo & 2 & Pištaline & 1 & Pištaline & 1 \\
\hline Čava & 2 & Čava & 2 & & & Ljusina & 1 \\
\hline Konjodor & 1 & Konjodor & 2 & & & & \\
\hline Lubarda & 2 & Lubarda & 2 & & & & \\
\hline
\end{tabular}

Table 3: Localities and infestation rates of D.kuriphilus (2016. i 2017.) on municipalities Bužim and Bosanska Krupa.

According to previous experiences with the expansion intensity of the chestnut gall wasp $[15,16]$, it can be expected that in coming years, occurrence of the gall wasp in new locations will move to a higher category of attack intensity. During next few years, intense emergence and spreading of chestnut gall wasp in other areas of Bosnia and Herzegovina can be expected. For now, the pest is not registered in the chestnut forests of the Herzegovina locality and of Eastern Bosnia. In the chestnut forests of this area, it is necessary to conduct a study of complexes of natural enemies, in particular parasites of chestnut gall wasps in Bosnia and Herzegovina. In the homeland of this pest, China, natural enemies, especially Hymenoptera parasites, effectively regulate its population [3]. It is also expected that indigenous parasites, very common in oak gall wasps, will adapt to the newborn pest [2]. In Italy, up until now, 16 species of indigenous parasites, has been adapted to the chestnut gall wasp, but with a low percentage of parasiticity for now [3]. Torymus sinensis Kamijo (Hymenoptera: Torymidae) is already used as a biological agent of suppression in Japan and Korea. 
Research shows its high efficiency [18]. In Italy, breeding experiments were carried out by releasing this parasite in nature. Genetic analysis confirmed the establishment of population in forests and plantations of sweet chestnut in Croatia and Slovenia [17].

Possibility of strengthening of chestnut blight fungus due to appearance of chestnut gall wasp in Bosnia and Herzegovina

In Europe, the disease was first observed in 1938 in northern Italy and it spread rapidly throughout Italy and neighboring countries [11]. In Slovenia, C. parasitica was first recorded in 1950 near Nova Gorica [7] and in Croatia near Opatija in 1955 [9]. The disease spread very fast and aggressively, and in 1961 it was recorded in Bosnia and Herzegovina [12]. In the chestnut forests of Una-Sana Canton, three groups of symptoms of cancer like formations were spotted: active cancer (AR), carcinogenic cancer (KR) and surface necrosis (PN) [7]. Prospero and Forster showed in research conducted in Switzerland that the new point of entry of the chestnut blight spores are most likely the galls from chestnut gall wasps. Here the spores are not transmitted through the insects, but through the galls, through which the spores enter, considering that the chestnut blight is a wound parasite $[9,10]$. The research was done on a sample of 24 young branches. In half of the examined branches, cancer symptoms were found, and there were no visible symptoms of the disease in the other 12 branches. It is assumed that the outflow holes of the gall wasp on the galls are the point of entry for the spores of the chestnut blight. After the grown wasp leaves, fungus can saprophytically inhabit the extinct tissue of the abandoned gall and then spread to the adjacent branches and initiate the formation of cancer substances.

\section{Conclusion}

Sweet chestnut (C. sativa) has been under a strong influence of 2 harmful biotic factors in Europe over the past 50 years. This refers to chestnut blight (C. parasitica), which caused great damage to chestnut forests. New pest that is threatening sweet chestnut, is the invasive, quarantine species, chestnut gall wasp. In Bosnia and Herzegovina it was first registered in 2015.The chestnut gall wasp is located at 41 location in Bosnia and Herzegovina in 2016, and in 2017 at 48 locations. During the study, it was found that the area of prevalence of chestnut gall wasp has spread to the locations of its first finding in 2015. However, the high intensity attacks of $D$. kuriphilus have been recorded on a large number of locations in 2017 as the gall wasp has spread and is present for 3 years. During next few years we can expect intensive emergence and spreading of chestnut gall wasps in other areas in Bosnia and Herzegovina (Herzegovinian locality and eastern Bosnia). In sweet chestnut forests of this area, it is necessary to conduct a study of complexes of natural enemies, in particular parasites of chestnut gall wasp in Bosnia and Herzegovina. Studies in Switzerland show that a new place for blight spores to enter could be the abandoned galls. Therefore, it is necessary to carry out studies to determine whether there is a risk for this type of infection spreading in the chestnut forests in Bosnia and Herzegovina.

\section{Bibliography}

1. Z Ács., et al. "The phylogenetic relationships between Dryocosmus, Chilaspis and allied genera of oak gallwasps (Hymenoptera, Cynipidae: Cynipini)". System Entomology 32 (2007): 70-80.

2. A Aebi., et al. "Parasitoid recruitment to the globally invasive chestnut gall wasp Dryocosmus kuriphilus, 103-121". In: Ecology and evolution of galling arthropods and their associates (Ozaki, K., Yukawa, J., Ohgushi, T., Price, P. W., Eds). SpringerVerlag, Tokyo, Japan (2006).

3. A Aebi., et al. "Native and introduced parasitoids attacking the invasive chestnut gall wasp Dryocosmus kuriphilus". EPPO Bulletin 37 (2007): 166-171.

4. M Conedera., et al. "Distribution and economic potential of the Sweet chestnut (Castanea sativa Mill.) in Europe". Ecology Medicine 30 (2004): 179-193.

5. G Csóka., et al. "The oriental sweet chestnut gall wasp (Dryocosmus kuriphilus Yasumatsu 1951) in Hungary". Növényvédelem 45 (2009): 359-360.

6. Z Delalić. Prvi nalaz karantenskog štetnika kestenove ose šiškarice (Drycosmus kuriphilus) na Unsko-sanskom kantonu (BiH), Biljni lekar (2006): 58-65.

7. Z Delalić., et al. "Pojava kestenove ose šiškarice (Dryocosmus kuriphilus) na Unsko-sanskom kantonu i povezanost sa rakom kore kestena (Cryphonectria parasitica)". Zbornik radova, 3rd International Conference, 462-468, Mostar. "NEW TECHNOLOGIES NT-2016", Development and Application (2006).

8. J Fernández-López and R Alía. Technical Guidelines for genetic conservation and use for chestnut (Castanea sativa) - EUFORGEN-NH (EUFORGEN- Noble Hardwoods), EUR (Regional Office for Europe) (2003).

9. M Glavaš. Gljivične bolesti šumskoga drveća. Zagreb, Šumarski fakultet (1999).

10. M Halambek. Istraživanje virulentnosti gljive Endothia parasitica (Murr.) and Uzročnika raka pitomoga kestena (Castanea sativa Mill.), disertacija, Šumarski fakultet, Sveucilište u Zagrebu (1998): 132.

11. U Heiniger and D Rigling. "Biological Control of Chestnut Blight in Europe". Annual Review of Phytopathology 32 (1994): 581-599.

12. M Ježić. Raznolikost gljive Cryphonectria parasitica Murrill Barr i njezin uticaj na populacije pitomog kestena (Castanea sativa Mill.), Doktorski rad, Prirodoslovno-matematički fakultet, Biološki odsjek, Sveučilište u Zagrebu (2013).

13. V Knapić., et al. "Experience with Dryocosmus kuriphilus Yatsumatsu erradication measures in Slovenia. OEPP/EPPO Bulletin 40 (2010): 169-175 
14. A Macanović. Ecological and syntaxonomic analysis of Sweet chestnut forests (Castanea sativa Mill.) in BiH. ANUBiH Sarajevo. Odjeljenje prirodnih i matematičkih nauka. Zbornik radova, Posebna izdanja. 343 (2012): 201-220

15. D Matošević., et al. Prvi nalaz kestenove ose šiškarice (Drycosmus kuriphilus), Šumarski list br (2010): 497-502.

16. D Matošević. Pojava, širenje i štetnost kestenove ose šiškarice (Dryocosmus kuriphilus) u Hrvatskoj, Radovi (Hrvat. šumar. inst.) 44 (2012): 113-124.

17. D Matošević., et al. Biološko suzbijanje invazivne kestenove ose šiškarice unesenom vrstom parazitoida T. sinensis u Hrvatskoj i Sloveniji, Zbornik sažetaka 61. seminara biljne zaštite (2017): 31-31.

18. S Moriya., et al. "Classical biological control of the chestnut gall wasp in Japan". Proceedings of the 1st International Symposium on Biological Control of Arthropods, ed. R.G.Van Driesche (2003): 407-15.

19. S Novak-Agbaba. "Monitoring raka kore pitomog kestena na trajnim plohama. Radovi Šumararski institute". Izvanredno izdanje 9 (2006): 199-211.

20. A Quacchia., et al. "Effectiveness of Torymus sinensis in the biological control of Dryocosmus kuriphilus in Italy". Acta Horticulture 1043 (2014): 199-204.

21. S Prospero and B Forster. "Chestnut gall wasp (Dryocosmus kuriphilus) infestations: new opportunities for the chestnut blight fungus Cryphonectria parasitica". New Disease Reports 23 (2011): 35.

22. LK Rieske. "Success of an exotic gallmaker, Dryocosmus kuriphilus, on chestnut in the USA: a historical account". Bulletin OEPP/EPPO Bulletin 37 (2007): 172-174.

23. C Sartor., et al. "Impact of the Asian wasp Dryocosmus kuriphilus (Yasumatsu) on cultivated chestnut: yield loss and cultivar susceptibility". Scientia Horticulturae 197 (2015): 454-460.

24. T Trešti. Rak pitomog kestena u Bosni i Hercegovini s posebnim osvrtom na populacionu strukturu patogena, Magistarski rad, Šumarski fakultet, Sarajevo (2000).

25. Y Wang., et al. "Microsatellite Loci Transf erability in Chestnut". Journal of the American Society for Horticultural Science 133 (2008): 692-700.

\section{Volume 3 Issue 9 September 2019 \\ (C) All rights are reserved by $\mathrm{Z}$ Delalić}

